\title{
Deteriorating Fiscal Outlook and Dependency of States on Centre in India
}

\author{
Tawqeer Fatima \\ Centre for Federal Studies/Jamia Hamdard University/ New Delhi
}

\begin{abstract}
The fiscal outlook of the subnational governments has continued to deteriorate as there has been a rapid increase in their expenditure on the one hand and the revenue receipts lagging behind on the other hand. Hence, Subnational governments are becoming more and more policy dependent as well as fiscally dependent on federal government. The fiscal containment movement, by undermining subnational governments' independent revenue bases, is providing one more large push toward fiscal dependence. Alongside increased fiscal dependence, the accumulating impact of great number of federal mandates on subnational governments is institutionalizing increasing policy dependence as well. States have been more depending on high cost borrowing for financing their plans, with very little own funds and decelerating central assistance. As a result, the interest burden has been rising. There has been a steady increase in the share of revenue expenditure across the states over time. The paper concludes and clearly indicates that the urgency and the need for remedial measures to be undertaken at the states' level if the deterioration in the fiscal health of the states is to be arrested.
\end{abstract}

Keywords: Centre, Dependency, Expenditure, Fiscal Deficit, State

\section{Introduction:}

The financial relations between the central government and subnational governments have not been satisfactory over the years. The demands of the states are very high and the capacity of the centre is very limited. There have been growing conflicts and tensions between these two layers of governments. The conflict is more severe where different political parties are in power at the centre and the states. The central government has used its powers to expand grants, share proceeds and loans to the states to keep its control over the states who desired to have certain financial independence. At the same time, this dependence of the states on the central government has resulted in fiscal indiscipline and irresponsibility at the state level. So that, the fiscal outlook of the subnational governments has continued to deteriorate as there has been a rapid increase in their expenditure on the one hand and the revenue receipts lagging behind on the other hand. Hence, Subnational governments are becoming more and more policy dependent as well as fiscally dependent on federal government. The fiscal containment movement, by undermining subnational governments' independent revenue bases, is providing one more large push toward fiscal dependence. Alongside increased fiscal dependence, the accumulating impact of great number of federal mandates on subnational governments is institutionalizing increasing policy dependence as well.

The study focused on fiscal dependency and its effect on fiscal outlook of states in India has been receiving wide attention; the issue at states' level has not been adequately analysed. In many respects, fiscal position in states' level is more critical than that at the centre. Risk to states' fiscal outlook include interest rate shocks, the dependency of states on the loans and grants from the centre, borrowing from the market and other sources has continued to increase, and rapid increase in the total expenditure of the states. This kind of a situation has been responsible for deteriorating fiscal condition of the states and in the process the states have been compelled to resort to increasing borrowing. The dependence of states on centre has been parasitic. It indicates the need for remedial measures to be undertaken at the states' level if the deterioration in the fiscal health of the states is to be arrested.

The remainder of the study is organized as follows:

The section (2) examines development and non developmental expenditure of states, section (3) deals with the pattern of receipts and expenditure of the states. Section (4) looks at the impact of financial dependency of the states on the central government and the section (5) examine the financing of state governments Gross Fiscal Deficit. Section (5) is conclusion. 


\section{Development and Non Development Expenditure of States:}

Table I shows that there has been a rapid increase in the total expenditure of the states, Rs.3294.3 billion in 2000-01 to Rs.6040.37 billion in 2006-07 (more than three times) and further to Rs.15125.32 billion in 2012-13 (budget) an increase more than five times as compared to 1991-92. A substantial increase in total expenditure of the states is accounted for by rapid increase in development and non developmental expenditures. Table I shows that development expenditure increases from Rs.2105.43 billion to Rs.10332.41billion in 2012-13. Developmental expenditure constituted 63.9 per cent of the total expenditure of the states in the year 2000-2001. This percentage increased to 68.4 in 2012-13 (budget). Table I shows that non developmental expenditure has significantly contributed to the increase in the total expenditure. During the period 2000-01 (Rs.1188.87 billion) to $2006-07$ (Rs.2118.72 billion) and further increased to Rs.4792.91 billion in 2012-13.[1] This kind of a situation has been responsible for deteriorating fiscal condition of the states and in the process the states have been compelled to resort to increasing borrowings.

Therefore, the problem of debt financing expenditure has continued to worsen the fiscal outlook of the states in the nation. While the subnational governments have continued to resort to increased borrowings, their dependence on the federal government has also increased over the years, table II shows that during the period $2000-01$ (Rs. 880.23 billion) to 2012-13 (Rs.948.17 billion), the quantum of states' share in central taxes and grants from the centre.

\section{(Table I) Development and Non development Expenditure of the States}

(Amount in Rs. Billion

Percentage is Percentage of the Item in Total Expenditure)

\begin{tabular}{|c|c|c|c|c|c|c|}
\hline Year & $\begin{array}{c}\text { Total } \\
\text { Expenditure } \\
(\text { TE) }\end{array}$ & Percentage & $\begin{array}{c}\text { Development } \\
\text { Expenditure } \\
(\mathbf{D E})\end{array}$ & Percentage & $\begin{array}{c}\text { Non Development } \\
\text { Expenditure } \\
\text { (NDE) }\end{array}$ & Percentage \\
\hline$(1)$ & $(2)$ & $(3)$ & $(4)$ & $(5)$ & $(6)$ & $(7)$ \\
\hline $2000-01$ & 3294.30 & 100.00 & 2105.43 & 63.9 & 1188.87 & 36.0 \\
\hline $2001-02$ & 3547.76 & 100.00 & 2166.96 & 61.1 & 1380.80 & 38.9 \\
\hline $2002-03$ & 3803.14 & 100.00 & 2284.16 & 60.1 & 1518.98 & 39.9 \\
\hline $2003-04$ & 4401.54 & 100.00 & 2740.80 & 62.3 & 1660.74 & 37.8 \\
\hline $2004-05$ & 4818.36 & 100.00 & 2935.37 & 60.9 & 1882.99 & 39.1 \\
\hline $2005-06$ & 5200.65 & 100.00 & 3300.44 & 63.5 & 1900.21 & 36.6 \\
\hline $2006-07$ & 6040.37 & 100.00 & 3921.65 & 64.9 & 2118.72 & 35.1 \\
\hline $2007-08$ & 6976.95 & 100.00 & 4644.62 & 66.6 & 2332.33 & 33.5 \\
\hline $2008-09$ & 8220.67 & 100.00 & 5670.86 & 68.9 & 2549.81 & 31.1 \\
\hline $2009-10$ & 9452.78 & 100.00 & 6377.31 & 67.5 & 3075.47 & 32.6 \\
\hline $2010-11$ & 10776.42 & 100.00 & 7203.55 & 66.8 & 3572.87 & 33.2 \\
\hline $2011-12$ & 13341.63 & 100.00 & 9208.76 & 69.0 & 4132.87 & 30.9 \\
\hline $2012-13$ & 15125.32 & 100.00 & 10332.41 & 68.4 & 4792.91 & 31.7 \\
\hline
\end{tabular}

Source: Reserve Bank of India, Handbook of Statistics on the Indian Economy, 2012-13.P.183

\section{Pattern of Receipts and Expenditure of the States:}

It is important to note that the contribution of states' share in central taxes and grants has been more than one in the total revenue receipts of the states throughout the period; it was around 38 per cent in 200-01 and 42 percent in the year 2012-13 respectively.[2] Table II also reveals the fact that states' dependence on the centre has been significant as a substantial part of the revenue expenditure of the states is financed by the central transfers in the form of states' share in central taxes and grants-in-aid.

(Table II) Pattern of Receipts and Expenditure of the States

\begin{tabular}{|c|c|c|c|c|c|}
\hline Year & $\begin{array}{l}\text { Total Revenue } \\
\text { Receipts }\end{array}$ & $\begin{array}{c}\text { Share in Central Taxes } \\
\text { and Grants from the } \\
\text { Centre }\end{array}$ & $\begin{array}{c}\text { (3) as Percentage of } \\
\text { (2) }\end{array}$ & $\begin{array}{c}\text { Revenue } \\
\text { Expenditure }\end{array}$ & $\begin{array}{c}\text { (3) as } \\
\text { Percentage of } \\
(5)\end{array}$ \\
\hline (1) & (2) & (3) & (4) & (5) & (6) \\
\hline $2000-01$ & 2325.09 & 880.23 & 37.9 & 2878.25 & 30.6 \\
\hline 2001-02 & 2494.22 & 948.17 & 38.1 & 3098.19 & 30.7 \\
\hline 2002-03 & 2736.74 & 1018.25 & 37.3 & 3308.53 & 30.8 \\
\hline 2003-04 & 3091.87 & 1179.16 & 38.2 & 3725.94 & 31.7 \\
\hline 2004-05 & 3635.12 & 1348.72 & 37.2 & 4026.70 & 33.5 \\
\hline $2005-06$ & 4310.21 & 1707.74 & 39.7 & 4380.34 & 38.9 \\
\hline 2006-07 & 5305.56 & 2147.44 & 40.5 & 5056.99 & 42.5 \\
\hline 2007-08 & 6237.48 & 2600.24 & 41.7 & 5808.05 & 44.8 \\
\hline 2008-09 & 6946.57 & 2909.75 & 41.9 & 6819.85 & 42.7 \\
\hline 2009-10 & 7681.36 & 3829.86 & 40.2 & 7991.54 & 39.6 \\
\hline
\end{tabular}


Deteriorating Fiscal Outlook and Dependency of States on Centre in India

\begin{tabular}{|c|c|c|c|c|c|}
\hline $2010-11$ & 9353.47 & 3829.86 & 40.9 & 9322.97 & 41.1 \\
\hline $2011-12$ & 11414.69 & 4836.15 & 42.4 & 11353.76 & 42.6 \\
\hline $2012-13$ & 13309.78 & 5660.12 & 42.6 & 12884.11 & 43.9 \\
\hline
\end{tabular}

Source: Reserve Bank of India, Hand Book of Statistics on the Indian economy 2012-13.P.181

\section{Financial Dependency of States on Centre:}

In addition, if one looks at the total resources transferred from the centre to the states as shown in table III, one would easily conclude that the fiscal dependence of the states on the centre has continued to increase. Table III shows that the quantum of total resource transfers from the centre to the states increased from Rs.1101190 million in 2000-01 to Rs.5325730 million in 2012-13 (budget) an increase of more than three times during the period. The contribution of such transfers in states, total expenditure has been substantial, though percentage of such transfers in financing the states' total expenditure has witnessed an increase in recent years.

(Table III) Fiscal Dependence of the states on the Centre

\begin{tabular}{|c|c|c|c|}
\hline Year & $\begin{array}{c}\text { Total Resources } \\
\text { transferred from the } \\
\text { Centre to the States }\end{array}$ & $\begin{array}{c}\text { Amount in Rs. Millions) } \\
\text { Total expenditure of the } \\
\text { States }\end{array}$ & $\begin{array}{c}\text { (2) as a } \\
\text { Percentage of } \\
(3)\end{array}$ \\
\hline$(1)$ & $(2)$ & $(3)$ & $(4)$ \\
\hline $2000-01$ & 1101190 & 3398350 & 32.4 \\
\hline $2001-02$ & 1205450 & 3686800 & 32.6 \\
\hline $2002-03$ & 1282390 & 4102490 & 31.2 \\
\hline $2003-04$ & 1412450 & 5143020 & 27.4 \\
\hline $2004-05$ & 1588380 & 5534280 & 28.9 \\
\hline $2005-06$ & 1752180 & 5616820 & 31.2 \\
\hline $2006-07$ & 2174850 & 6572800 & 33.1 \\
\hline $2007-08$ & 2686830 & 7523240 & 35.8 \\
\hline $2008-09$ & 2931840 & 8823330 & 33.3 \\
\hline $2009-10$ & 3168530 & 10153300 & 31.3 \\
\hline $2010-11$ & 3906830 & 11587300 & 33.9 \\
\hline $2011-12$ & 4514270 & 14330840 & 31.6 \\
\hline $2012-13$ & 5325730 & 16322410 & 32.7 \\
\hline
\end{tabular}

Source: Government of India, Ministry of Finance, Indian Public finance Statistics, 2012-13. P.79

The states' dependence on the centre for tax revenue share or assistance transfer has a three pronged intricacy. One is the dependence aspect itself i.e., the states, rich or poor, are dependent on the centre, the second is the degree of its heaviness, i.e., it is heavy dependence, not uniformly or evenly distributed among the different states, and the third, the dependence is a rising entity (the logistics of dependence), the factors which tender to this phenomenon a permanent character, and constantly contribute to its growth.

Over the years the dependence of most states on the centre for assistance (loans 70 per cent, grants 30 per cent; loan 10 per cent and grant 90 per cent) grew to serious proportions. This growth can be ascribed, to a great extent, to their pathetic financial position, which was instrumental in the decision and lack of initiative detected on their part most of the while. Turning to the centre for bailing and help which originated in distinct form around the mid-1980s the states developed this into routine, customary affairs, almost as a habit. But precedent to that epoch, since the independence, and soon after as one of the edicts of the constitution, the centre extended to the states the facility of assistance, steadily making them addicted to borrowing from it and becoming more and more dependent on it, by putting the fiscal theology of sound finance into the cold storage. Many believe that the centre was keen to engineer a situation like this for ensuring its political ends. We know that it is through pulling the levers of positive and negative subventions that the political system intervenes smoothly in the economic system. As a Finance Commission remarked much later, the states' dependence on the centre for loans provided the centre with an enormous power to affect the decision making process at the state level and to mount pressures on the state governments.[3]

The irony of the fiscal system is this that the states are dependent on the centre for loans but not viceversa (in emergent conditions the states do donate to the centre). By some stretch of the imagination, we could say that what is the UN to India with regard to aid and loans, the central government is to the state governments. After all, a federation is a sort of the commonwealth of a number of states, a union without unity.

The dependence of the states on the centre has been indicated as parasitic. But the states have their own argument to justify their dependence, that their resources are not commensurate with their obligations and responsibilities, and included in their resources are those earmarked to them by the centre, namely, the statutory and plan assistance and discretionary transfers. The loans element is so very paramount that it defies all their 
endeavours to break out of the vicious circle of indebtedness. More concretely, the real problem is one of the financial mismatches between the states' growing economic responsibilities and the levels of mobilization of their own tax revenue, which has reached a saturation point, according to their contention but is still low according to the centre. The centre, for example, urges that in charging the user's cost to the users of the public services (e.g., irrigation water supply by the government canals and public tubewells) the records of the states is black. To this the states' reply is that the record of the centre in this field is not better - the pot can hardly the kettle black.[4]

Most states assert that the gap between their own resources and their needs has kept on widening, which is the reason why they turned to the centre more and more for assistance. They put another factor ancillary to it as the persuader, that the RBI's holdings of the state governments' loans are small; conclusively, their dependence on the centre is high.

The states indicate that the centre raises more revenue than for its own functioning. By contrast, they raise fewer resources than they need being constituents of a federal polity with a federal fiscal system there is the natural transfer of resources from the centre to themselves.

But the states' continuing dependence on the centre has its cost. Let us submit the following by way of illustration; first, distortion have been generated in the centre-states relations. Next, the financial self sufficiency has been affected. Thirdly, the states' expenditure pattern has developed rigidity which has grown with time. Fourthly, improvidence has increased on the part of the states. Fifthly, the states are a demoralized set, going out to the centre with a begging bowl in their hands.[5]

Most of the states have voiced their grievances and protested against their financial weaknesses and fiscal dependence on the centre. Which are listed below;

1. The states need fiscal independence so as to have friendly relation with the centre. A strong centre and fiscal dependence on the centre are not in the interest of the integrity of India in the long run, since fiscal disputes between the two sets of government would acts as a divisive force and would be harmful to the unity of India.

2. The centre has been expanding the number and scope of its functions, assuming more and more powers, which has subordinated the states, making them weaker and dependent on the centre.

3. Though the functions of the centre are limited in number, it has allotted too much financial resources to itself keeping the states at its feet for financial aid.

4. The financial resources of the states being inelastic and stationary, the states are put to great strains. They have to depend on the centre for their financial needs.

5. Taxes of the states and their share in the central taxes being inadequate, the states have to depend greatly on loans and grant-in-aid from the centre. Therefore, this has created uncertainty and instability. Like a child depending upon his parents for its survival, the states have lost their fiscal independence and initiative. Either they have to follow the footsteps of the centre or starve of financial aid.

Thus, the states in India are deprived of economic independence to their continuous dependence on the centre for additional funds.

\section{Financing of State Governments Gross Fiscal Deficit:}

The dependence of states on the loans from the centre, borrowing from the market and other sources has continued to increase, as it clear from table IV. As a consequence, the states' total outstanding liabilities have also continued to increase over the years. States' total outstanding liabilities during the period 2000-01 (Rs.5112.4 billion) to 2006-07 (Rs.10604.3 billion) became double. Such liabilities which stood at Rs.11313.7 billion in 2007-08, became double at Rs.18823.0 in 2012-13 (Revised). In the year 2013-14 (budget), states' total outstanding liabilities further increased and stood at RS.21275.2 billion. The continuous increase in the total outstanding liabilities of the states is a clear indication of deterioration in the finances of the state governments as also of gross mis-management in states' fiscal affairs.

(Table IV) Financing of State Governments Gross Fiscal Deficit

\begin{tabular}{|c|c|c|c|c|c|c|c|}
\hline \multirow[t]{2}{*}{ Year } & \multirow{2}{*}{$\begin{array}{l}\text { Loans from } \\
\text { central } \\
\text { government }\end{array}$} & \multirow{2}{*}{$\begin{array}{l}\text { Market } \\
\text { Borrowin } \\
\text { g } \\
\end{array}$} & \multirow[t]{2}{*}{ Others* } & \multirow{2}{*}{$\begin{array}{l}\text { Gross Fiscal } \\
\text { Deficit } \\
(2+3+4) \\
\end{array}$} & \multicolumn{3}{|c|}{$\begin{array}{l}\text { State Outstanding Liabilities } \\
\text { (As at end March) }\end{array}$} \\
\hline & & & & & Total** & $\begin{array}{l}\text { Loans and } \\
\text { advances } \\
\text { from the } \\
\text { Centre }\end{array}$ & $\begin{array}{l}\text { Market } \\
\text { Loan }\end{array}$ \\
\hline (1) & (2) & (3) & (4) & (5) & (6) & (7) & (8) \\
\hline $2000-01$ & $\begin{array}{l}187.1 \\
(18.9)\end{array}$ & $\begin{array}{l}133.0 \\
(13.5)\end{array}$ & $\begin{array}{l}670.79 \\
(67.7) \\
\end{array}$ & $\begin{array}{l}990.89 \\
(100.0)\end{array}$ & 5112.4 & 2386.6 & 867.7 \\
\hline 2001-02 & $\begin{array}{l}244.0 \\
(22.4)\end{array}$ & $\begin{array}{r}187.1 \\
(17.2)\end{array}$ & $\begin{array}{c}661.16 \\
(60.6)\end{array}$ & $\begin{array}{c}1092.26 \\
(100.0)\end{array}$ & 5980.0 & 2495.5 & 1040.3 \\
\hline $2002-03$ & 268.3 & 308.5 & 716.15 & 1292.95 & 6888.9 & 2491.8 & 1330.7 \\
\hline
\end{tabular}


Deteriorating Fiscal Outlook and Dependency of States on Centre in India

\begin{tabular}{|c|c|c|c|c|c|c|c|}
\hline & $(20.75)$ & $(23.9)$ & $(55.4)$ & $(100.0)$ & & & \\
\hline 2003-04 & $\begin{array}{l}258.7 \\
(19.1)\end{array}$ & $\begin{array}{r}505.2 \\
(37.3)\end{array}$ & $\begin{array}{l}594.05 \\
(43.8)\end{array}$ & $\begin{array}{c}1357.95 \\
(100.0)\end{array}$ & 7915.9 & 1929.8 & 1799.2 \\
\hline 2004-05 & $\begin{array}{l}258.8 \\
(17.5) \\
\end{array}$ & $\begin{array}{l}391.0 \\
(26.5) \\
\end{array}$ & $\begin{array}{c}829.96 \\
(56.1) \\
\end{array}$ & $\begin{array}{c}1479.76 \\
(100.0) \\
\end{array}$ & 8859.4 & 1600.5 & 2134.8 \\
\hline $2005-06$ & $\begin{array}{r}81.0 \\
(7.8) \\
\end{array}$ & $\begin{array}{r}217.3 \\
(20.8) \\
\end{array}$ & $\begin{array}{l}748.23 \\
(71.6) \\
\end{array}$ & $\begin{array}{c}1046.53 \\
(100.0) \\
\end{array}$ & 9965.8 & 1570.5 & 2289.2 \\
\hline 2006-07 & $\begin{array}{r}57.2 \\
(5.5) \\
\end{array}$ & $\begin{array}{c}266.0 \\
(25.2) \\
\end{array}$ & $\begin{array}{c}733.12 \\
(69.5) \\
\end{array}$ & $\begin{array}{c}1056.32 \\
(100.0) \\
\end{array}$ & 10604.3 & 1466.5 & 2427.8 \\
\hline $2007-08$ & $\begin{array}{r}72.5 \\
(6.6)\end{array}$ & $\begin{array}{r}805.7 \\
(73.1)\end{array}$ & $\begin{array}{c}224.63 \\
(20.4)\end{array}$ & $\begin{array}{c}1102.83 \\
(100.0)\end{array}$ & 11313.7 & 1451.0 & 2985.1 \\
\hline 2008-09 & $\begin{array}{c}70.0 \\
(4.2) \\
\end{array}$ & $\begin{array}{l}1290.8 \\
(77.2)\end{array}$ & $\begin{array}{l}313.09 \\
(18.8)\end{array}$ & $\begin{array}{c}1673.89 \\
(100.0) \\
\end{array}$ & 12550.6 & 1438.7 & 4019.2 \\
\hline $2009-10$ & $\begin{array}{r}81.1 \\
(3.9) \\
\end{array}$ & $\begin{array}{l}1181.9 \\
(57.9)\end{array}$ & $\begin{array}{l}778.71 \\
(38.2)\end{array}$ & $\begin{array}{c}2041.81 \\
(100.0)\end{array}$ & 14173.4 & 1431.5 & 5157.9 \\
\hline $2010-11$ & $\begin{array}{l}94.8 \\
(3.9) \\
\end{array}$ & $\begin{array}{c}1572.0 \\
(65.9)\end{array}$ & $\begin{array}{l}719.75 \\
(30.2)\end{array}$ & $\begin{array}{c}2386.55 \\
(100.0)\end{array}$ & 15687.8 & 1441.7 & 6040.9 \\
\hline $2011-12$ & $\begin{array}{c}99.0 \\
(4.4)\end{array}$ & $\begin{array}{l}1678.6 \\
(74.2)\end{array}$ & $\begin{array}{c}486.71 \\
(21.5)\end{array}$ & $\begin{array}{c}2264.31 \\
(100.0)\end{array}$ & 17198.7 & 1435.5 & 7411.5 \\
\hline $2012-13$ & $\begin{array}{c}202.1 \\
(6.9)\end{array}$ & $\begin{array}{c}2187.1 \\
(73.7)\end{array}$ & $\begin{array}{c}267.16 \\
(9.0)\end{array}$ & $\begin{array}{c}2967.86 \\
(100.0)\end{array}$ & 18823.0 & 1504.1 & 8746.0 \\
\hline
\end{tabular}

Source: Reserve Bank of India, Annual Report 2012-13. P.95; Handbook of Statistics on the Indian Economy RBI, 2012-13. P.184

Note: Figures in brackets are percentages to the Gross Fiscal Deficit

*includes loans from financial institutions, Provident Funds, Reserve Funds, Deposits and advances, Special Securities issued to NSSF,etc

**includes internal debt, loans and advances from the centre and provident funds, etc.

Table IV also shows that in the context of increasing outstanding liabilities of the states, loans and advances from the centre so also the quantum of market loans have continued to increase throughout the period. During the period March 2001 (Rs.867.7 billion) to March 2014 (Rs.10907.8 billion), outstanding market loans witnessed an increase of more than five times (from Rs.867.7 to Rs.10907.8 billion) during the period. This data clearly indicates the urgency and the need for remedial measures to be undertaken at the states' level if the deterioration in the fiscal health of the states is to be arrested.

Fiscal transfers to the states, through all channels as percentage of the Gross Revenue Receipts of the centre increased from an average of 31.4 per cent in the period of the Sixth Finance Commission to 38.1 per cent for the Seventh Finance Commission. It further increases to 40.3 per cent for the period covered by the Ninth Finance Commission before coming down to 35.8 per cent during the period of the Tenth Finance Commission. During the period of Eleventh Finance Commission, transfers to the states have remained above 4 per cent of GDP.[6] Determining the right size of fiscal deficit and debt in relation to GDP is important for prudent fiscal management.

\section{Conclusion:}

Deteriorating Fiscal outlook of state governments in India is a case of worry. More worrisome is the fact by and large, state finances are deteriorating further with the obvious consequence of the central government finances. Hence, Finances of states are in worst shape. The states' increasingly large deficits mean their fiscal policy is an important factor not only in their own performance but overall fiscal sustainability deteriorating finances have caused state spending in India. Interest amount on debt is presently more that what the state government spends on all economic services like agriculture, irrigation, hydropower etc. The receipts on revenue account have lagged behind the expenditure on revenue account and thus the states have been faced to resort to increased borrowings from the union government as also from the market and other sources. This is reflected in the increasing interest bill of the state governments. The debt policy of the state governments needs to be reoriented. Economy in expenditure wherever possible and avoidance of wasteful expenditure should not only be accepted in principle but ought to be practiced in various departments of the state governments if the goal of fiscal discipline is to achieved and fiscal dependency of states on centre will have to be balanced.

\section{References:}

[1]. Reserve Bank of India, Handbook of Statistics on the Indian Economy, 2012-13.P.183

[2]. Thirteenth Finance Commission Report, Government of India, 2010-15

[3]. Prasad, Kedarnath. Development of India's Financial System, Sarup \& Sons, New Delhi p.222.

[4]. Singh.S.K. Public Finance in Theory and Practice, S. Chand \& Company Ltd, New Delhi, P.508

[5]. Prasad, Kedarnath. Development of India's Financial System, op.cit.,p.224

[6]. Government of India, Twelfth Finance Commission Report (2005-10) 


\section{Official Reports:}

> Government of India, Ministry of Finance, Indian Public finance Statistics, 2012-13.

$>$ Reserve Bank of India, Handbook of Statistics on the Indian Economy, 2012-13.

$>$ Reserve Bank of India, Annual Report 2012-13. 